\title{
EFFECT OF BESTATIN ON MOUSE IMMUNE SYSTEM AND EXPERIMENTAL MURINE TUMORS
}

\author{
Masaaki Ishizuka, Toru Masuda, Nobuo Kanbayashi, Shigeki Fukasawa, \\ Tomio Takeuchi, Takanki Aoyagi and Hamao Umezawa \\ Institute of Microbial Chemistry \\ 14-23 Kamiosaki 3-Chome, Shinagawa-ku, Tokyo, Japan
}

(Received for publication March 10, 1980)

\begin{abstract}
Effect of bestatin on the establishment of delayed-type hypersensitivity (DTH) to sheep red blood cells (SRBC) and oxazolone was examined in normal and immunity-impaired mice. Administration of a low dose of bestatin $(0.1 \sim 100 \mu \mathrm{g} /$ mouse $)$ augmented DTH to SRBC and restored their impaired DTH to oxazolone. The effect of bestatin in the mouse was agedependent. Bestatin retarded the growth of slow growing solid tumors of GARDNER lymphosarcoma and IMC carcinoma and the effect was influenced by the time of the administration and the number of cells inoculated. Bestatin enhanced the antitumor action of the antitumor antibiotics, bleomycin and adriamycin. Bestatin also retarded the induction of skin cancer by 20 -methylcholanthrene.
\end{abstract}

Bestatin is a strong inhibitor of aminopeptidase B and leucine aminopeptidase ${ }^{1 \sim 4)}$ and binds to the cell surface including lymphocytes and macrophages ${ }^{4 \sim 6)}$. As reported previously ${ }^{6)}$, bestatin in a wide dose range augments the establishment of delayed-type hypersensitivity to sheep red blood cells and a high dose more than $1 \mathrm{mg} /$ mouse increases the number of cells forming IgM antibody to heterologous red blood cells in mice. Bestatin is a dipeptide, [(2S,3R)-3-amino-2-hydroxy-4-phenylbutanoyl]-Lleucine ${ }^{2)}$ and has a extremely low toxicity.

In this paper we report the immuno-potentiating activities of bestatin and its effect on murine transplantable tumors.

\section{Materials and Methods}

Mice

$\mathrm{CDF}_{1}$ mice (Balb/c $\times \mathrm{DBA} 2$, male or female, $4 \sim 14$ weeks old) were supplied by Institute of Medical Science, University of Tokyo. $\mathrm{C} 3 \mathrm{H} / \mathrm{He}$ mice (female, 8 weeks old), $d d Y$ mice (female, 6 weeks old) and ICR mice (female, $8 \sim 10$ weeks old) were purchased from Shizuoka Agricultural Cooperative Association for Laboratory Animals. These mice were housed in plastic filter top cages and fed sterilized mouse pellet (MB-1, Funabashi Farm Co., Ltd. Chiba, Japan) and water ad libitum.

Bestatin

Bestatin (Lot. 751158TS) was prepared by Nippon Kayaku Co., Ltd. following the instruction of the authors ${ }^{1)}$. This was used throughout this study. For animal experiments, bestatin was dissolved in distilled water at 1 or $4 \mathrm{mg} / \mathrm{ml}$ and diluted. Mice were given an appropriate dose of bestatin in $0.25 \mathrm{ml}$.

Treatment with cyclophosphamide

Cyclophosphamide ("Endoxan", Shionogi Co. Ltd., Osaka, Japan) was dissolved in distilled water at $16 \mathrm{mg} / \mathrm{ml}$, and $0.25 \mathrm{ml}$ of the solution containing 4 or $6 \mathrm{mg}$ of cyclophosphamide was intraperitoneally injected to each mouse.

Treatment with anti-lymphocyte serum

Rabbit anti-mouse lymphocyte serum (ALS) was prepared by the method described by LEVEY and 
MEDWAR $^{7)}$ and the serum was treated with an acetone powder of mouse liver or mouse red cells and diluted with phosphate buffer saline (PBS): $800 \sim 1,600$ times diluted ALS killed 100\% of thymic cells $\left(1 \times 10^{8}\right)$ of $\mathrm{CDF}_{1}$ mice in the presence of complement and $0.25 \mathrm{ml}$ of 10 times diluted ALS was intraperitoneally injected to mice daily for 3 days to reduce DTH response to sheep red blood cells.

Delayed-type hypersensitivity (DTH) to sheep red blood cells (SRBC)

The effect on DTH to SRBC was tested by the method described by LAGRANGe et al. ${ }^{8)}$. CDF mice (female, $4 \sim 10$ weeks old) were immunized by subcutaneous injection of $10^{8} \mathrm{SRBC}$ in $0.05 \mathrm{ml}$ of saline into the right hind paw. Four days thereafter, DTH response was elicited by injection of $10^{8}$ SRBC into the left hind paw and 24 hours thereafter, the resulting edema of the left hind paw was measured with a caliper. The thickness increase of the left hind paw in units of $0.1 \mathrm{~mm}$ was obtained from the difference between the thickness of the left footpad and that of right footpad. SRBC was employed within 3 weeks after bleeding.

Delayed-cutaneous hypersensitivity $(\mathrm{DCH})$ to oxazolone ${ }^{9)}$

Oxazolone (4-ethoxymethylene-2-phenyl-2-oxazolin-5-one, Aldrich Chemical Company, Inc., Milwaukee, Wis., U.S.A.) was dissolved in absolute ethyl alcohol at $5 \%(\mathrm{w} / \mathrm{v})$. The abdomen of each mouse $\left(\mathrm{CDF}_{1}\right.$, female, 10 weeks old) was shaved and sensitized by painting $0.1 \mathrm{ml}$ of oxazolone solution. After 48 hours the reaction was elicited by painting $0.1 \mathrm{ml}$ of oxazolone solution on the footpad of the left hind paw. Fourty eight hours thereafter, $\mathrm{DCH}$ response was determined by measuring the resulting edema by a caliper. The thickness increase in $0.1 \mathrm{~mm}$ of the left hind paw was obtained from the differences between the thickness of the reaction-elicited footpad and that of the other footpad. Oxazolone solution was freshly prepared in each experiment.

Antitumor antibiotics

Both bleomycin ("Bleo", Nippon Kayaku Co., Ltd., Tokyo, Japan) and adriamycin (Kyowa Hakko Co., Ltd., Tokyo, Japan) were dissolved in saline and $0.25 \mathrm{ml}$ of their solutions was injected intraperitoneally.

Murine transplantable tumors

IMC carcinoma, GARDNER's lymphosarcoma and L-1210 were used as syngeneic tumors and EHRLich carcinoma was used as an allogeneic tumor. These tumors had been transferred at 7-day intervals in each mouse strain.

In 1975, a spontaneously-induced ascitic tumor was found in pooled $\mathrm{CDF}_{1}$ mouse (female, 15 weeks old). This tumor can be transferred only through $\mathrm{CDF}_{1}$ mice in the ascitic form. Pathological and morphological properties of this tumor have been studied by Dr. EGASHIRA in NIH, Japan and this tumor was named IMC carcinoma. To $\mathrm{CDF}_{1}$ mice (female, 11 weeks old), $10^{8}$ or $5 \times$ $10^{6}$ IMC cracinoma cells were subcutaneously inoculated to the inguinal area and after the inoculation the size of each tumor was daily measured. As shown in Fig. 1, there was a lag time of about 10 days and thereafter the tumor continue to grow at the almost constant rate up to $5 \sim 6$ weeks. Mice died within $61.4 \pm 3.3$ or $48.8 \pm 3.9$ days after the inoculation of $1 \times 10^{8}$ or $5 \times 10^{8}$ cells respectively. This tumor was chosen for the test of antitumor activity of bestatin. Ascitic tumor cells collected 5 days after the intraperitoneal inoculation were washed with saline or DULBECCo's PBS and the cell suspension containing an adequate number of cells was prepared. The tumor

Fig. 1. The growth of IMC carcinoma after its subcutaneous inoculation to $\mathrm{CDF}_{1}$ mice.

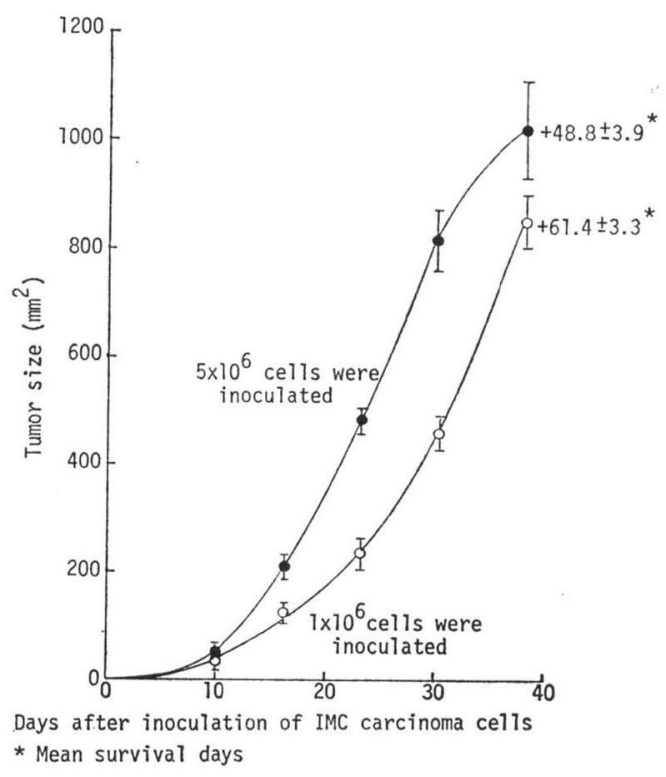


cells in $0.25 \mathrm{ml}$ were injected subcutaneously to groin of $\mathrm{CDF}_{1}$ mouse.

GARDNER's lymphosarcoma (6C3HED-OG) was maintained by intraperitoneal inoculation of ascitic cells to $\mathrm{C} 3 \mathrm{H} / \mathrm{He}$ mice. For experiment, ascitic tumor cells of from 5 to 7 days after the inoculation were collected, washed, and suspended at $4 \times 10^{5} \mathrm{cells} / \mathrm{ml}$ in saline, and $10^{5}$ cells were inoculated subcutaneously at groin of each $\mathrm{C} 3 \mathrm{H} / \mathrm{He}$ mouse to produce a solid tumor.

Ascitic lymphoid leukemia L-1210 was maintained in $\mathrm{CDF}_{1}$ mice, and $10^{5}$ cells were intraperitoneally injected in experiments where the antitumor effect of bestatin was tested in combination with adriamycin.

EHRLICH ascites tumor was maintained in female out bred ICR or $d d Y$ mice. In experiment where the effect on footpad tumors was tested, ascitic tumor cells of from 5 to 7 days after the intraperitoneal inoculation of tumor cells were washed with saline thoroughly and suspended in saline at $2 \times 10^{7} \mathrm{cells} / \mathrm{ml}$. The tumor cell suspension $(0.05 \mathrm{ml})$ was inoculated to the footpad of left hind paw subcutaneously. In order to test the effect on secondary tumors 7 days after the first inoculation, the same number of tumor cells were inoculated to the footpad of the other hind paw. The tumor size in $0.1 \mathrm{~mm}$ was recorded by measuring the thickness of footpad by a caliper. In the experiment testing the effect on the ascites tumor, 1 or $2 \times 10^{6}$ cells in $0.25 \mathrm{ml}$ were intraperitoneally injected to $d d Y$ or ICR mice.

Induction of skin cancer in mice by 20 -methylcholanthrene

Mice ( $d d Y$, female, 11 weeks old) were shaved at back near neck every week and two drops of saturated 20-methylcholanthrene (20-MC, Eastman Organic Chemicals, Rechester, N. Y., U.S.A.) in acetone was painted twice a week for 10 weeks. Each mouse was weighed every week and the induction of cancer was checked. 20-Methylcholanthrene-induced skin tumors were confirmed to be squamous cell carcinoma by pathological examination.

Table 1. Effect of bestatin on DTH response to SRBC.

\begin{tabular}{|c|c|c|}
\hline \multicolumn{2}{|r|}{ Immunized with ${ }^{1)}$} & \multirow{2}{*}{$\begin{array}{c}\begin{array}{c}\text { Increase of } \\
\text { footpad thickness }\end{array} \\
(\times 0.1 \mathrm{~mm}, \pm \text { S.D. }) \\
6.7 \pm 0.9\end{array}$} \\
\hline $10^{8} \mathrm{SRBC}$ s. c. & & \\
\hline $10^{8}$ SRBC s. c. & Bestatin $1,000 \mu \mathrm{g} / \mathrm{mouse}$ oral & $9.8 \pm 0.7$ \\
\hline " & $100 \mu \mathrm{g} / \quad " \quad$ & $10.5 \pm 1.1$ \\
\hline$"$ & $10 \mu \mathrm{g} / \quad " \quad$ & $11.4 \pm 1.2$ \\
\hline$"$ & $1 \mu \mathrm{g} / \quad "$ & $11.4 \pm 0.9$ \\
\hline$"$ & $0.1 \mu \mathrm{g} / \quad n$ & $9.1 \pm 1.3$ \\
\hline
\end{tabular}

1) Mice were given bestatin at time of immunization. Each group consisted of 5 mice.

Table 2. Influence of mouse age on the effect of bestatin in enhancing DTH to SRBC.

\begin{tabular}{|c|c|c|c|c|c|c|}
\hline \multirow{3}{*}{$\mu \mathrm{g} /$ mouse $^{2)}$} & \multicolumn{6}{|c|}{ Age of mice ${ }^{1)}$} \\
\hline & \multicolumn{2}{|l|}{4 weeks } & \multicolumn{2}{|l|}{8 weeks } & \multicolumn{2}{|l|}{14 weeks } \\
\hline & $\begin{array}{c}\text { Increase of } \\
\text { footpad thickness }^{33}\end{array}$ & $\mathrm{~T} / \mathrm{C} \%$ & $\begin{array}{c}\text { Increase of } \\
\text { footpad thickness }\end{array}$ & $\mathrm{T} / \mathrm{C} \%$ & $\begin{array}{c}\text { Increase of } \\
\text { footpad thickness }\end{array}$ & $\mathrm{T} / \mathrm{C} \%$ \\
\hline 0 & $8.6 \pm 0.2$ & & $8.1 \pm 0.9$ & & $8.1 \pm 1.5$ & \\
\hline 0.1 & $8.0 \pm 0.5$ & 93 & $9.9 \pm 0.7$ & 122 & $13.1 \pm 0.8$ & 162 \\
\hline 1.0 & $9.6 \pm 1.5$ & 112 & $10.5 \pm 0.8$ & 130 & $14.0 \pm 0.7$ & 173 \\
\hline 10.0 & $9.0 \pm 1.9$ & 105 & $12.5 \pm 1.0$ & 154 & $13.8 \pm 0.8$ & 170 \\
\hline 100.0 & $8.3 \pm 2.0$ & 97 & $10.4 \pm 0.8$ & 128 & $12.9 \pm 0.5$ & 159 \\
\hline $1,000.0$ & $7.6 \pm 1.5$ & 88 & $9.3 \pm 0.7$ & 115 & $9.9 \pm 1.0$ & 122 \\
\hline
\end{tabular}

1) $\mathrm{CDF}_{1}(\mathrm{Balb} / \mathrm{c} \times \mathrm{DBA} / 2)$ male mice

2) Oral administration at the time of immunization

3) Increase of footpad thickness $(\times 0.1 \mathrm{~mm}, \pm$ S.D.) 


\section{Results}

\section{Effect of Bestatin on DTH to SRBC}

$\mathrm{CDF}_{1}$ mice (male, 8 weeks old) were immunized by subcutaneous injection of $10^{8} \mathrm{SRBC}$ into footpad of right hind paw and each dose of bestatin was injected intraperitoneally at the same time. Four days thereafter, SRBC was injected to the footpad of left hind paw and 24 hours thereafter, DTH response was examined by measuring the thickness of the resulting edema elicited in left footpad. As shown in Table 1, oral administration of bestatin at the time of immunization augmented the establishment of DTH to $\mathrm{SRBC}$ in doses of $1 \mu \mathrm{g}$ to $100 \mu \mathrm{g}$ /mouse. The same result, however, was not obtained in several other laboratories. Therefore, the effect of bestatin was checked under various conditions and it was confirmed that the effect of bestatin on DTH to SRBC was dependent the mouse age. As shown in Table 2, although the degree of response to SRBC, that is, the thickness of edema was not significantly different among 4, 8 and 14 weeks old $\mathrm{CDF}_{1}$ female mice, the effect of bestatin was different in mice of different ages. In mice of 4 weeks old, the augmentation of DTH response was not observed. In case of 8 weeks old, oral administration of $1 \sim 100 \mu \mathrm{g}$ of bestatin/mouse at the time of immunization showed the enhancement of DTH response. The DTH in the 14 weeks old mice showed stronger response to $0.1 \sim 100 \mu \mathrm{g}$ /mouse of bestatin. In all cases, the highest dose of bestatin, $1 \mathrm{mg} /$ mouse, did not enhanced DTH response. The optimal dose in enhancing the response was $10 \sim 100 \mu \mathrm{g} /$ mouse.

The effect of bestatin on DTH response was tested in following different mouse strains: female C57$\mathrm{BL} / 6, \mathrm{C} 3 \mathrm{H} / \mathrm{He}, \mathrm{DBA} / 2$ and $\mathrm{Balb} / \mathrm{c}$ of 13 to 14 weeks old. In addition to $\mathrm{CDF}_{1}$ mouse, $\mathrm{DBA} / 2$ and $\mathrm{C} 3 \mathrm{H} / \mathrm{He}$ were susceptible to the action of bestatin in augmenting DTH response to SRBC.

Routes of administration of bestatin to enhance DTH was examined by the footpad test. The enhancing effect was seen following intravenous, intraperitoneal and oral administration of 1,10 or $100 \mu \mathrm{g} /$ mouse of bestatin, but not with subcutaneous route of administration. Higher doses of bestatin by subcutaneous injection enhanced DTH to SRBC.

Mice were given $10 \mu \mathrm{g}$ of bestatin orally on various days before or after the immunization with SRBC and their DTH response to SRBC was tested. Oral administration of bestatin $1 \sim 6$ days before immunization and 0,1,2,3 days after immunization was effective in enhancing DTH. Bestatin was most effective when given a day before and $0 \sim 3$ days after immunization. The best timing of bestatin

Table 3. Effect of bestatin on DTH response to $\mathrm{SRBC}$ in mice immunized by intravenous injection of SRBC.

\begin{tabular}{crr|r}
\hline \multicolumn{2}{c|}{ Immunized with } & \multicolumn{1}{c}{$\begin{array}{c}\text { Increase of } \\
\text { footpad thickness } \\
(\times 0.1 \mathrm{~mm}, \\
\pm \text { S.D. })\end{array}$} \\
\hline $10^{5}$ SRBC i.v. & & $8.6 \pm 0.9$ \\
$10^{5}$ SRBC i.v. Bestatin $1,000 \mu \mathrm{g}^{1)}$ & $8.7 \pm 1.4$ \\
$" \prime$ & " & $100 \mu \mathrm{g}$ & $9.5 \pm 1.1$ \\
$" \prime$ & $10 \mu \mathrm{g}$ & $16.2 \pm 1.3$ \\
$" \prime$ & $1 \mu \mathrm{g}$ & $12.2 \pm 0.9$ \\
" & " & $0.1 \mu \mathrm{g}$ & $13.5 \pm 1.1$ \\
\hline
\end{tabular}

1) Bestatin was given orally at the time of the immunization.
Table 4. Effect of bestatin on DTH response to SRBC in mice treated with anti-lymphocyte serum (ALS).

\begin{tabular}{crr|r}
\hline & & $\begin{array}{c}\text { Increase of } \\
\text { footpad thickness } \\
(\times 0.1 \mathrm{~mm}, \\
\pm \text { S.D. })\end{array}$ \\
\hline Non-treated & & $6.4 \pm 0.8$ \\
ALS-treated & & $2.3 \pm 0.1$ \\
$"$ " Bestatin & $1,000 \mu \mathrm{g}$ & $5.1 \pm 0.4$ \\
$" \prime$ & " & $100 \mu \mathrm{g}$ & $3.7 \pm 0.4$ \\
& $10 \mu \mathrm{g}$ & $3.5 \pm 0.5$ \\
\hline
\end{tabular}


administration to enhance DTH appeared to be the day of immunization or 1 day thereafter. The effect of consecutive administration of bestatin was examined on DTH response. Mice ( $d d Y$, female, 8 weeks old) were immunized and were given $1 \mu \mathrm{g}$ of bestatin orally on day 1 or days 1,2 or days 1,2 and 3 after immunization. A single administration of bestatin at day 1 was the most effective regimen. Bestatin administration initiated 2 days after the immunization was least effective. As reported previously ${ }^{8}$, the administration of bestatin at the time of the eliciting injection of SRBC was not effective.

The effect of bestatin in enhancing DTH produced by intravenous injection of $10^{5} \mathrm{SRBC}$ was tested. $\mathrm{CDF}_{1}$ mice (female, 10 weeks old) were immunized by intravenous injection of $10^{5} \mathrm{SRBC}$ and were given different doses of bestatin orally. Four days later, $10^{8}$ SRBC were subcutaneously injected to footpad of left hind paw and after 24 hours, the thickness of resulting edema in each mouse was measured. As shown in Table 3, the lower doses of bestatin $(0.1,1$ or $10 \mu \mathrm{g} /$ mouse $)$ were markedly effective in augmenting DTH response. The optimal dose was $10 \mu \mathrm{g} /$ mouse. High doses of bestatin, 100 or $1,000 \mu \mathrm{g} /$ mouse did not show a significant effect.

Table 5. Effect of bestatin on DTH response to $\mathrm{SRBC}$ in mice bearing EHRLICH ascites tumor.

\begin{tabular}{|c|c|c|c|}
\hline & & & $\begin{array}{l}\text { Increase of } \\
\text { footpad thickness } \\
\begin{array}{r}(0.1 \mathrm{~mm}, \\
\pm \text { S.D. })\end{array}\end{array}$ \\
\hline \multicolumn{3}{|c|}{ Tumor-free } & $6.8 \pm 0.5$ \\
\hline \multicolumn{3}{|c|}{ Tumor-bearing } & $0.6 \pm 0.1$ \\
\hline " & \multicolumn{2}{|c|}{ Bestatin $1,000 \mu \mathrm{g}$} & $1.0 \pm 0.1$ \\
\hline$"$ & " & $100 \mu \mathrm{g}$ & $0.4 \pm 0.06$ \\
\hline " & $"$ & $10 \mu \mathrm{g}$ & $5.4 \pm 1.3$ \\
\hline$"$ & " & $1 \mu \mathrm{g}$ & $3.8 \pm 1.1$ \\
\hline
\end{tabular}

$2 \times 10^{6}$ cells of EHRLICH ascites tumor cells were inoculated, 4 days thereafter, mice were immunized by inoculation of SRBC to footpad. Bestatin was given once orally at the time of the immunization.

Table 6. Effect of bestatin on delayed-cutaneous hypersensitivity to oxazolone in mice.

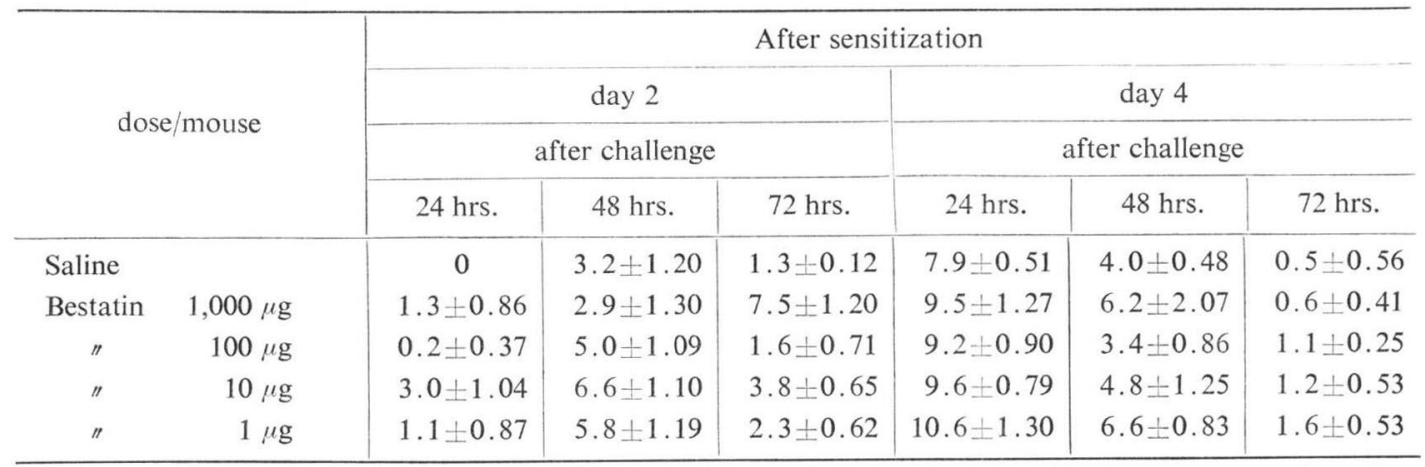

Mice were sensitized by painting $0.1 \mathrm{ml}$ of $5 \%$ oxazolone in ethanol and 2 days or 4 days thereafter, bestatin given orally. The same volume of oxazolone was painted to footpad. The resulting edema was measured 24, 48 and 72 hours after the second oxazolone painting.

Table 7. Antitumor effect of bestatin in different schedules on IMC carcinoma.

\begin{tabular}{c|c|c|c|c}
\hline \multirow{2}{*}{$\begin{array}{c}\text { Bestatin dose } \\
\text { in } \mu \mathrm{g} / \text { mouse/day }\end{array}$} & \multicolumn{4}{|c}{ Therapy on days and \% inhibition (range) } \\
\cline { 2 - 5 } & $-7 \sim-1$ & $1 \sim 5$ & $8 \sim 12$ & $14 \sim 18$ \\
\hline 1 & & $43.1(51.5 \sim 26.8)$ & $48.7(88.6 \sim 0)$ & $55.0(76.4 \sim 3.2)$ \\
10 & & $41.7(75.0 \sim 26.2)$ & $82.0(88.6 \sim 75.5)$ & $71.0(84.2 \sim 58.4)$ \\
100 & $42.3(90.7 \sim 0)$ & $36.3(63.4 \sim 0)$ & $71.6(81.8 \sim 60.6)$ & $71.3(80.5 \sim 61.5)$ \\
\hline
\end{tabular}

1) Bestatin was administered orally. $10^{6}$ Tumor cells were implanted s.c. to $\mathrm{CDF}_{1}$ mice on day 0 . Mice were sacrificed and tumors were weighed day 30. Mean weight of tumors from non-treated mice was $10.310 \mathrm{~g}$. 
Table 8. Antitumor effect of bestatin against GARDNER's lymphosarcoma (6C3HED-OG).

\begin{tabular}{l|r|r|c}
\hline & $\begin{array}{c}\text { Bestatin } \\
\text { dose } \\
\mu \mathrm{g} / \text { mouse } \\
\text { /day }\end{array}$ & $\begin{array}{c}30 \text {-day } \\
\text { mean w.t. in } \\
\text { mg (range) }\end{array}$ & $\begin{array}{c}\% \% \\
\text { Inhibition }\end{array}$ \\
\hline $\begin{array}{l}\text { Exp. I } \\
4 \text { mice/group }\end{array}$ & 0 & $\begin{array}{c}741.0 \\
(658 \sim 863)\end{array}$ & - \\
\hline & 100 & $\begin{array}{c}215.0 \\
(50 \sim 437)\end{array}$ & 71.0 \\
\hline Exp. II & 0 & $\begin{array}{c}1375.3 \\
(570 \sim 2174) \\
303.0\end{array}$ & - \\
\hline mice/group & 10 & $\begin{array}{c}307.9 \\
(105 \sim 561) \\
551.8\end{array}$ & 59.9 \\
& 100 & $(93 \sim 947)$ & \\
\hline
\end{tabular}

1) Mice were given bestatin orally daily for 5 days.

Table 10. Antitumor effect of the combination treatment of bestatin with bleomycin (BLM) on EHRLICH carcinoma produced by primary and secondary inoculation of tumor cells.

\begin{tabular}{|c|c|c|c|c|}
\hline \multirow{2}{*}{$\begin{array}{l}\text { Treated } \\
\text { with }^{1)}\end{array}$} & \multicolumn{2}{|c|}{ Primary tumor } & \multicolumn{2}{|c|}{ Secondary tumor } \\
\hline & $\begin{array}{c}\begin{array}{c}\text { Tumor } \\
\text { size }^{2)} \\
(\times 0.1 \mathrm{~mm})\end{array} \\
\end{array}$ & $\begin{array}{c}\% \text { Inhi- } \\
\text { bition }\end{array}$ & $\begin{array}{c}\begin{array}{c}\text { Tumor } \\
\text { size }^{22} \\
(\times 0.1 \mathrm{~mm})\end{array} \\
\end{array}$ & $\begin{array}{c}\% \text { Inhi- } \\
\text { bition }\end{array}$ \\
\hline None & 37.5 & 0 & 23.2 & 34 \\
\hline $\begin{array}{l}\text { BLM } \\
100 \mu \mathrm{g} / \\
\text { mouse }\end{array}$ & 28.8 & 23 & 20.5 & 42 \\
\hline $\begin{array}{l}\text { Bestatin } \\
10 \mu \mathrm{g} / \\
\text { mouse }\end{array}$ & 36.0 & 4 & 14.4 & 59 \\
\hline$\underset{\text { bestatin }}{\mathrm{BLM}+}$ & 21.4 & 43 & 0 & 100 \\
\hline $\begin{array}{l}\text { (Second- } \\
\text { ary } \\
\text { tumor } \\
\text { alone) }\end{array}$ & - & - & 35.3 & 0 \\
\hline
\end{tabular}

1) Day $1 \sim 6$, daily, i.p.

2) Results on 14 days after primary or secondary inoculation of $10^{6}$ EHRLICH ascites tumor cells to footpad. The standard deviation does not exceed $15 \%$.
Table 9. Effect of bestatin with or without bleomycin on footpad tumor of EHRLICH carcinoma.

\begin{tabular}{|c|c|c|c|c|}
\hline \multirow{3}{*}{$\begin{array}{l}\text { Bestatin } \\
(\mu \mathrm{g} / \\
\text { mouse })\end{array}$} & \multicolumn{4}{|c|}{ Bestatin with } \\
\hline & \multicolumn{2}{|c|}{ None } & \multicolumn{2}{|c|}{$\begin{array}{c}\mathrm{BLM}^{1)} \\
(100 \mu \mathrm{g} / \text { mouse })\end{array}$} \\
\hline & $\begin{array}{c}\text { Tumor } \\
\text { size }^{2)} \\
(\times 0.1 \mathrm{~mm})\end{array}$ & $\begin{array}{l}\% \text { Inhi- } \\
\text { bition }\end{array}$ & $\begin{array}{c}\text { Tumor } \\
\left.\text { size }^{2}\right) \\
(\times 0.1 \mathrm{~mm})\end{array}$ & $\begin{array}{l}\% \text { Inhi- } \\
\text { bition }\end{array}$ \\
\hline 0 & 48.9 & 0 & 44.9 & 8 \\
\hline 1,000 & 59.3 & 0 & 46.1 & 6 \\
\hline 100 & 73.5 & 0 & 0 & 100 \\
\hline 10 & 49.6 & 0 & 0 & 100 \\
\hline 1 & 49.4 & 0 & 22.6 & 78 \\
\hline
\end{tabular}

1) Bleomycin, day $1 \sim 6$, daily, i. p.

2) 30 days after implantation of tumor cells. The standard deviation does not exceed $15 \%$.

The effect of bestatin on DTH to SRBC in mice in which the immune system was impaired by inoculation of EHRLICH ascites tumor or by treatment with ALS was studied. $d d Y$, Female, 8 weeks old mice were injected with $0.25 \mathrm{ml}$ of diluted ALS daily for 3 days. On day 4, they were immunized by subcutaneous injection with $10^{8} \mathrm{SRBC}$ to footpad. Different doses of bestatin were given orally and its effect was determined by the footpad test. Results are shown in Table 4. Compared to normal mice, DTH response of ALS-treated mice was markedly reduced, but bestatin treatment restored the reduced DTH. A high dose of bestatin ( $1 \mathrm{mg} /$ mouse) was more effective than 100 or $10 \mu \mathrm{g} /$ mouse. $d d Y$, Female 8 weeks old mice were inoculated with $2 \times 10^{6}$ cells of EHRLICH ascites tumor intraperitoneally, and 4 days later $10^{8} \mathrm{SRBC}$ were injected into footpad.

Different doses of bestatin were given orally at the same time. Five days later, mice were challenged by injection of SRBC to the other footpad and the thickness of resulting edema was measured.

As shown in Table 5, compare to normal mice, DTH response was markedly impaired in tumorbearing mice. Bestatin in low doses (10 or $1 \mu \mathrm{g} /$ mouse) restored the reduced DTH response by 78 or $56 \%$. Higher doses of bestatin, 100 or $1,000 \mu \mathrm{g} /$ mouse, did not restore the reduced DTH.

Effect of Bestatin on Delayed-Cutaneous Hypersensitivity to Oxazolone

Effects of bestatin on DCH to oxazolone in non-treated mice and in immunity-impaired mice were studied.

Mice ( $\mathrm{CDF}_{1}$, female, $11 \sim 12$ weeks old) were sensitized by painting $0.1 \mathrm{ml}$ of $5 \%$ oxazolone on the shaved abdomen. Bestatin $(1,10,100$ or $1,000 \mu \mathrm{g} /$ mouse) was given orally. Two or four days later, 
oxazolone solution was painted on the footpad of hind paw to elicite the reaction, and 24, 48 and 72 hours later the resulting edema was measured. As shown in Table 6, when the second oxazolone solution was painted 2 days after the sensitization, the maximal response was observed at 48 hours and when the second oxazolone solution was painted 4 days after the sensitization the maximal response was observed at 24 hours thereafter. This assay method was employed to test the effect of bestatin on DCH to oxazolone in following experiments.

To $\mathrm{CDF}_{1}$ mice $6 \mathrm{mg}$ of cyclophosphamide was injected intravenously and bestatin (10 or 1,000 $\mu \mathrm{g} /$ mouse) was administered orally once a day for 5 successive days. Six days after the treatment with cyclophosphamide, mice were sensitized by painting oxazolone and challenged 2 days later by painting oxazolone solution. The response to oxazolone in mice treated with cyclophosphamide was markedly suppressed and the administration of bestatin restored the suppressed response as follows: the thickness of edema; $0.68 \pm 0.09 \mathrm{~mm}$ in mice without cyclophosphamide treatment; $0.20 \pm 0.05 \mathrm{~mm}$ in mice treated with cyclophosphamide; $0.88 \pm 0.05 \mathrm{~mm}$ in mice treated with cyclophosphamide and $10 \mu \mathrm{g}$ bestatin; $0.89 \pm 0.07 \mathrm{~mm}$ in mice treated with cyclophosphamide and $1,000 \mu \mathrm{g}$ bestatin.

To mice $10^{6}$ EHrLich ascites tumor cells were implanted, 4 days later, oxazolone solution was painted on the shaved abdomen and a single oral dose of bestatin $(0.1,10,100 \mu \mathrm{g} /$ mouse $)$ was administered. The thickness of edema was as follows: tumor-free mice, $0.68 \pm 0.09 \mathrm{~mm}$; EHRLICH carcinomabearing mice; without bestatin, $0.21 \pm 0.13 \mathrm{~mm}$; bestatin $0.1 \mu \mathrm{g}, 0.78 \pm 0.15 \mathrm{~mm}$; bestatin $10 \mu \mathrm{g}, 0.7 \pm$ $0.11 \mathrm{~mm}$; bestatin $1,000 \mu \mathrm{g}, 0.73 \pm 0.17 \mathrm{~mm}$. The $\mathrm{DCH}$ response to oxazolone was markedly reduced by EHRLICH ascites tumor and the administration of bestatin at the time of the sensitization restored the reducing response to the level of tumor-free mice. Bestatin treatment did not prolong the survival period of mice bearing EHRLICH ascites tumor.

\section{Effect of Bestatin on Murine Transplantable Tumors}

Effects of bestatin on syngeneic or allogeneic murine transplantable tumors were tested. At the beginning of this study, we examined whether bestatin could exhibit inhibition against EHRLICH ascites carcinoma and leukemia L-1210. EHRLICH ascites tumor cells $\left(2 \times 10^{3}\right.$ cells $)$ or L-1210 cells $\left(1 \times 10^{5}\right.$ cells $)$ were inoculated to ICR (female, 6 weeks old) or $\mathrm{CDF}_{1}$ mice (female, 8 weeks old) intraperitoneally and then after, $1,10,100$ or $1,000 \mu \mathrm{g} /$ mouse of oral bestatin was administered daily for 10 days. Bestatin did not influence the survival period of mice.

Bestatin showed effects in inhibiting IMC carcinoma and GARDner lymphosarcoma. To $\mathrm{CDF}_{1}$ mice (female, 10 weeks old) $10^{8}$ IMC carcinoma cells were inoculated to groin and 1,10 or $100 \mu \mathrm{g} / \mathrm{mouse}$ bestatin was given daily orally for 5 days in different schedules: bestatin treatment was started from 1, 5, 8 and 14 days after the inoculation of tumor cells or 7 days before the inoculation. Thirty days after the inoculation, tumors were extirpated and weighed. As shown in Table 7, the administration of $100 \mu \mathrm{g} /$ mouse/day bestatin for 5 days before the inoculation and the administration of 1,10 or 100 $\mu \mathrm{g} /$ mouse/day bestatin started from one day after the inoculation was somewhat effective in suppressing the growth of the tumor, but the effect was fluctuated in each mouse. The administration of bestatin started on day 8 for 14 days after the inoculation suppressed the growth of the tumor. As shown in Table 7, there was no dose-dependency, although 10 or $100 \mu \mathrm{g} / \mathrm{mouse} /$ day orally seemed to be the optimal dose to suppress the growth of this tumor. The administration of a high dose such as $1,000 \mu \mathrm{g} / \mathrm{mouse} /$ days was not effective. As shown in Fig. 2, the treatment of $10 \mu \mathrm{g} /$ mouse bestatin on day 8 after the inoculation of tumor cells showed the greatest effect. 
Fig. 2. Antitumor effect of bestatin treatment on IMC carcinoma started on 1,8 , or 14 days after the inoculation of tumor cells.

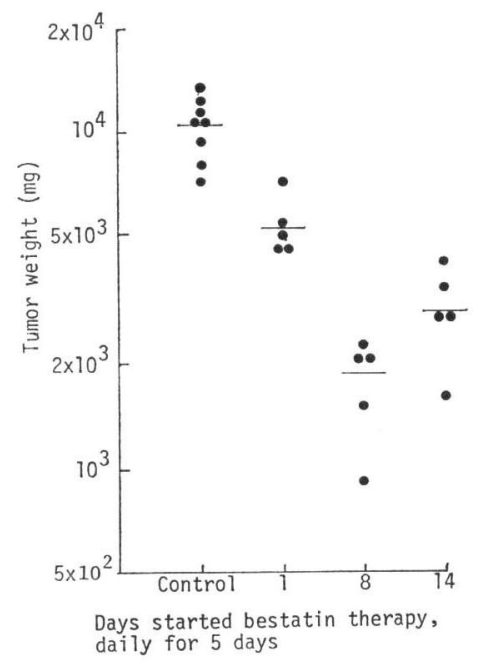

In the other experiment, the influence of the number of tumor cells inoculated on the effect of bestatin was examined. Mice $\left(\mathrm{CDF}_{1}\right.$, female, 11 weeks old) were inoculated $10^{5}, 10^{8}$ or $10^{7} \mathrm{IMC}$ carcinoma cells ( 5 mice for each group) and 10 $\mu \mathrm{g} /$ mouse of bestatin was given daily orally from 8 days to 12 days after the inoculation of tumor cells. The result is shown in Fig. 3. The antitumor effect of bestatin was more marked when a smaller number of tumor cells were inoculated. of the growth of tumor, when $10^{7}$ cells were inoculated.

The effect of bestatin was tested on a subcutaneous solid tumor of GARDNER's lymphosarcoma. Mice (C3H/He, female, 8 weeks old) were implanted $10^{5}$ ascitic GARDNER's lymphosarcoma cells to groin subcutaneously and 10 or $100 \mu \mathrm{g}$ /mouse oral bestatin was given daily for 5 days from one day to 5 days after the implantation of tumor cells. Thirty days later, tumors were extirpated and weighed. As shown in Table 8, 10 or $100 \mu \mathrm{g} /$ mouse/day inhibited the tumor growth by $60 \sim 78 \%$.

The effect of bestatin in combination with bleomycin or adriamycin was studied. When $10^{6}$ EHRLICH ascites tumor cells were inoculated to footpad of hind paw of $d d Y$ mice subcutaneously, the maximal tumor growth was observed in $2 \sim 3$ weeks after the inoculation without spontaneous regression. Bleomycin and other antitumor substances which are known to be effective against ascites and solid forms of EHRLICH carcinoma were ineffective in the footpad tumor. In an experiment $10^{6}$ EHRLICH carcinoma cells were inoculated to hind footpad, from day $1,100 \mu \mathrm{g}$ of bleomycin, 1, 10, 100 or 1,000 $\mu \mathrm{g} /$ mouse of bestatin alone or both of them were given daily intraperitoneally for 6 successive days. Thirty days after the implantation, the size of each tumor was recorded in $0.1 \mathrm{~mm}$. As shown in Table 9, although $100 \mu \mathrm{g}$ of bleomycin or each dose of bestatin alone was ineffective in suppressing the tumor, the 
treatment of $100 \mu \mathrm{g}$ or $10 \mu \mathrm{g}$ of bestatin in combination with $100 \mu \mathrm{g}$ of bleomycin completely inhibited the growth of the tumor.

In this allogeneic system, the effect of bestatin in rejecting the secondary tumor was studied. As indicated in Table 10, $10^{6}$ EHrLICH carcinoma cells were inoculated to footpad of right hind paw to produce the primary tumor. Bleomycin alone, bestatin alone or bleomycin with bestatin was given daily for 6 days starting day 1 after the transplantation of tumor cells, and 7 days after the inoculation of tumor cells $10^{8}$ tumor cells were inoculated to the other hind footpad to produce the secondary tumor. Fourteen days after the inoculation the size of each primary and secondary tumor in footpad was measured. As shown in Table 10, although the treatment with bleomycin or bestatin alone inhibited growth of the secondary tumor by $42 \%$ or $59 \%$ respectively, the treatment of bleomycin $(100 \mu \mathrm{g} / \mathrm{mouse})$ with bestatin $(10 \mu \mathrm{g} /$ mouse) rejected the secondary tumor.

The effect of bestatin in enhancing the effect of adriamycin against L-1210 was studied: $10^{5} \mathrm{~L}-1210$ cells were inoculated intraperitoneally to $\mathrm{CDF}_{1}$ mice, from day $1,20 \mu \mathrm{g} /$ mouse of adriamycin was given daily intraperitoneally for 3 days and $10 \mu \mathrm{g}$ or $100 \mu \mathrm{g} /$ mouse of bestatin was given daily orally for 10 days. The mean survival days and the number of survived mice 30 days after the inoculation of tumor cells were as follows: adriamycin alone, 15.2 days, 0 out of 5 ; adriamycin and $100 \mu \mathrm{g}$ bestatin, $>18.7$

Fig. 4. Effect of bestatin in retarding the induction of skin cancer in mice by $20 \mathrm{MC}$.
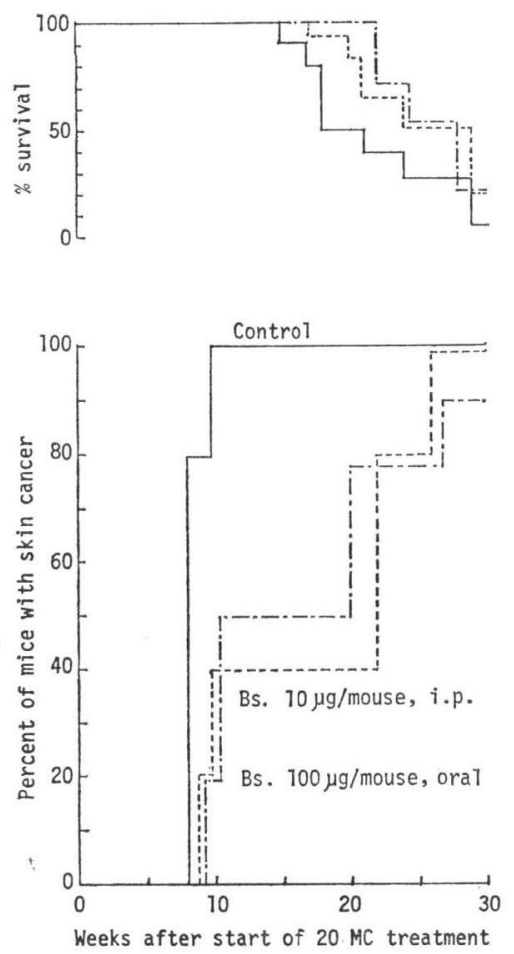

days, 1 survived mice out of 6 ; adriamycin and 10 $\mu \mathrm{g}$ bestatin, $>20.7$ days, 2 out of 6 .

Effect of Bestatin on Induction of Skin Cancer by 20-Methylcholanthrene in Mice

The influence of bestatin on induction of skin cancer by 20 -methylcholanthrene (20-MC), was examined. A portion of the back around the neck of mice ( $d d Y$, female, 11 weeks old) were shaved and two drops of saturated 20-MC in acetone was painted twice a week for 10 weeks. Bestatin administration was started at the same time as $20-\mathrm{MC}$ treatment. Bestatin was given twice a week for 15 weeks. Each group consisted of 20 mice. As shown in Fig. 4, within 8 to 10 weeks after the start of the painting of 20-MC, skin cancer was induced in mice which were not treated with bestatin. Although in $25 \sim 32$ weeks after the start of 20-MC-painting skin cancer was induced in almost all mice to which bestatin was administered, the administration of $100 \mu \mathrm{g} /$ mouse/day orally or $10 \mu \mathrm{g} / \mathrm{mouse} /$ day intraperitoneally of bestatin retarded the induction of skin cancer.

\section{Discussion}

Administration of bestatin at the time of immunization augmented the establishment of delayed- 
type hypersensitivity to SRBC in a wide dose range. The optimal dose for enhancing DTH to SRBC was in the range of $1 \sim 100 \mu \mathrm{g} /$ mouse. In order to see the effect of bestatin in enhancing DTH, it was necessary to test it on aged mice, that is, those older than 8 or 10 weeks. Bestatin augmented DTH when it was administered intraperitoneally, intravenously and orally. The administration through subcutaneous route was not useful in evaluating the effect of bestatin. It has been reported that in the delayed-cutaneous hypersensitivity to oxazolone in mice, $\mathrm{T}$ cell/macrophage mediated events are involved in early response, and $\mathrm{B}$ cells in late response ${ }^{10)}$. HemsworTH et al. ${ }^{11)}$ reported that tumorassociated or drug-induced anergy to oxazolone was a suitable model for evaluation of the activity of compounds. We studied the optimal condition in testing bestatin effect on DCH to oxazolone: the method which the thickness of edema is measured 48 hours after the oxazolone painting to elicite the reaction appears to give the best result. We examined the effect of bestatin on the early DCH response to oxazolone in mice which were treated with cyclophosphamide or inoculated with EHRLICH ascites tumor. Administration of bestatin before the sensitization restored the anergy induced by injection of cyclophosphamide. Bestatin also restored the reduced DCH to oxazolone response in EHRLICH ascites tumor-bearing mice to that of tumor-free mice. Bestatin showed a strong action in restoring the reduced $\mathrm{DCH}$ to oxazolone.

These effects of bestatin on delayed-type hypersensitivity to SRBC and to oxazolone indicate that bestatin enhances the establishment of cell-mediated immune responses and restores the reduced functions of cell-mediated immune reactions. Mechanisms of action of bestatin in enhancing immune responses have been studied by testing the mitogenic action of bestatin on murine splenic lymphocytes, and as will be reported in the following paper ${ }^{12)}$, it has been suggested that bestatin causes the proliferation of $\mathrm{T}$ cells through the activation of macrophages.

Antitumor effect of bestatin was examined on syngeneic or allogeneic murine tumors. Bestatin was ineffective in suppressing EHRLICH ascites tumor or L-1210. Against the solid form of IMC carcinoma, as syngeneic tumor, oral administration of bestatin retarded the growth of the tumor, when bestatin treatment was started 8 or 14 days after the inoculation of tumor cells. The tumor growth after the inoculation of smaller number of tumor cells was more susceptible to bestatin treatment than a large number of cells such as $10^{7}$. Since mice die about 40 to 60 days after the inoculation of 1 or $5 \times 10^{6}$ cells/mouse of IMC carcinoma, IMC carcinoma seems to be a slowly growing tumor in which defense mechanisms are somewhat preserved. The antitumor activity of bestatin on this tumor may depend on the stimulation of the defense mechanisms.

Against fast growing tumors such as EHRLICH carcinoma and L-1210, bestatin enhanced the therapeutic effect of adriamycin and bleomycin. The mechanism of this synergistic effect may be explained as follows. The destruction of cancer cells by antitumor substances may decrease the release of immunosuppressive products from cancer cells and bestatin may enhance the defense mechanism or destroy cells which may produce antigens free from cells.

Bestatin retarded the induction of skin cancer by 20-MC. Small molecular weight immunomodulators such as bestatin may be useful in analysis of immune mechanisms in cancer patients.

\section{Acknowledgements}

This work was partly supported by a Grant-in-Aid for Cancer Research from the Ministry of Education, Science and Culture, Japan and a Contract No. NO1-CM-57009 from the Division of Cancer Treatment, National Cancer Institute, U.S.A.

\section{References}

1) Umezawa, H.; T. Aoyagi, H. Suda, M. Hamada \& T. Takeuchi: Bestatin, an inhibitor of aminopeptidase B produced by actinomycetes. J. Antibiotics 29: $97 \sim 99,1976$

2) Suda, H.; T. Takita, T. Aoyagi \& H. Umezawa: The structure of bestatin. J. Antibiotics 29: 100 101,1976

3) Suda, H.; T. Aoyagi, T. Takeuchi \& H. Umezawa: Inhibition of aminopeptidase B and leucine aminopeptidase by bestatin and its stereoisomer. Arch. Biochem. Biophys. 177: 196 200, 1976 
4) Umezawa, H.: Recent advances in bioactive microbial secondary metabolites. Jap. J. Antibiotics (Suppl.) 30: 138 163, 1977

5) Aoyagi, T.; H. Suda, M. Nagai, K. Ogawa, J. Suzuki, T. Takeuchi \& H. Umezawa: Aminopeptidase activities on the surface of mammalian cells. Biochim. Biophys. Acta 452: 131 143, 1976

6) Umezawa, H.; M. Ishizuka, T. Aoyagi \& T. Takeuchi: Enhancement of delayed-type hypersensitivity by bestatin, an inhibitor of aminopeptidases. J. Antibiotics 29: 857 859, 1976

7) Levey, R. H. \& P. B. MedwaR: Nature and mode of activation of anti lymphocytic antiserum. Proc. Natl. Acad. Sci. U.S.A. 56: 1130 1137, 1966

8) Lagrange, P. H.; G. B. Mackaness \& T. E. Miller: Influence of dose and route of antigen injection on the immunological induction of T cells. J. Exp. Med. 139: 528 542, 1974

9) Griswald, D. E.; J. A. Dilorenzo \& P. Calabresi: Quantification and pharmacological dissection of oxazolone-induced sensitivity in the mouse. Cell Immunol. 11: 198 204, 1974

10) Davies, A. J. S.; R. L. CARTer, E. Leuchars \& V. Willis: The morphology of immune reactions in normal, thymectomized, and reconstituted mice. II. The response to oxazolone. Immunology 17: 111 126, 1969

11) Hemsworth, G. R.; J. S. Wolff, III, A. R. Kraska \& K. E Jensen: Delayed cutaneous hypersensitivity to oxazolone in mice with tumors. Cancer Res. 38: 907 910, 1978

12) Ishizuka, M.; J. Sato, Y. Sugiyama, T. Takeuchi \& H. Umezawa: Mitogenic effect of bestatin on lymphocytes. J. Antibiotics 33: 653 662, 1980 